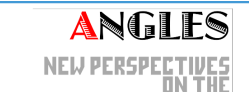
ANELOPHONE WORLD

\section{Angles}

New Perspectives on the Anglophone World

$4 \mid 2017$

Unstable States, Mutable Conditions

\title{
The Summer Garden Photograph, Or a Barthesian Reading of the Mutable Poetics of Louise Glück
}

\section{Marie Olivier}

\section{(2) OpenEdition}

1 Journals

\section{Electronic version}

URL: https://journals.openedition.org/angles/1516

DOI: 10.4000/angles. 1516

ISSN: 2274-2042

\section{Publisher}

Société des Anglicistes de l'Enseignement Supérieur

\section{Electronic reference}

Marie Olivier, "The Summer Garden Photograph, Or a Barthesian Reading of the Mutable Poetics of Louise Glück", Angles [Online], 4 | 2017, Online since 01 April 2017, connection on 08 June 2022. URL: http://journals.openedition.org/angles/1516; DOl: https://doi.org/10.4000/angles.1516

This text was automatically generated on 8 June 2022.

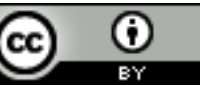

Angles est mise à disposition selon les termes de la Licence Creative Commons Attribution 4.0 International. 


\title{
The Summer Garden Photograph, Or a Barthesian Reading of the Mutable Poetics of Louise Glück
}

\author{
Marie Olivier
}

June 9, 1978

(Mourning)

Not continuous, but immobile.

Roland Barthes, Mourning Diary (149)

Since the publication of the collection Averno (2006), and more particularly since A Village Life (2009), contemporary American poet Louise Glück has explored a new rhythm and adopted what one might consider a more narrative style: her poems expand along longer lines that ebb and flow right into the margins of the page. This new stylistic departure was confirmed in her latest collection, Faithful and Virtuous Night (2014), where the expansive lines of the long poems (some cover more than six pages) alternate with prose poems.

2 In this context, it may seem paradoxical that the long poem "A Summer Garden" should appear to be so vividly geared towards disappearance. This change of pace in Glück's style shows the poet's persistent irresolution between lyrical urgency, utter silence and lyrical expansion, resulting in a poetics whose strength appears impregnable, now more so than ever. It endows it with a challenging vitality, with a force of resistance against the void which Glück's personae keep pushing away. Since the kaleidoscopic poems of The Triumph of Achilles, published in 1985, her voice and breath have grown through longer poems, each divided into several numbered parts. The turn from the terse and economical poems of Firstborn (1968) to the long lines and prose poems of Faithful and Virtuous Night (2014) seems to offer formal evidence of what one may consider a fluctuating poetics. As Helen Vendler asserts in an essay about Jorie Graham's poetry: "When a poet ceases to write short lines and begins to write long lines, that change is a breaking of style almost more consequential, in its implications, than any other" (Vendler 304). In "Disruption, Hesitation, Silence," published in 1994 in 
her collection of essays, Proofs and Theories (Glück 1994: 73), the American poet famously explained:

In my generation, most of the poets I admire are interested in length: they want to write long lines, long stanzas, long poems, poems which cover an extended sequence of events. To all this I feel an instant objection, whose sources I'm not confident I know. [...] What I share with my friends is ambition; what I dispute is its definition. I do not think that more information always makes a richer poem. I am attracted to ellipsis, to the unsaid, to suggestion, to eloquent, deliberate silence. The unsaid, for me, exerts great power: often I wish an entire poem could be made in this vocabulary. It is analogous to the unseen; for example, to the power of ruins, to works of art either damaged or incomplete.

Glück's turning to prose poems and longer verse may not be such a radical change, but rather a change of poetics, a change in the making. I will argue that the intention, however, has not moved. Her poems never describe any event in "exhaustive detail" (73). Even though her lines have lengthened, they are still structured on the basis of "eloquent, deliberate silence" that is not to be found in fewer words, not in "more language," or as she explains further in the same essay, in some "work that is all detail and no shape" 2 (82), but in a textual structure that challenges silence and plays on the edge of the abyss, playing on the transitive ambiguity of her words. Through a close reading of the poem, the article proposes to analyze how Glück's mutable poetics tries to serve the unsaid and how it relies on instability to do so; how the stammering quality of the poem's language challenges and even shuns a presupposed "narrative turn." In this poem, sometimes saying more means saying less and less, to the point of muteness.

In the five-part poem "A Summer Garden" (Glück 2014: 64-70), Glück's persona wipes the dust off of an old photograph of her mother sitting in a garden. The picture seems to be caught between an immobile past and a moving sense of time that unavoidably comes to a point of annihilation:

I

Several weeks ago I discovered a photograph of my mother

sitting in the sun, her face flushed as with achievement or triumph.

The sun was shining. The dogs

were sleeping at her feet where time was also sleeping,

calm and unmoving as in all photographs.

I wiped the dust from my mother's face.

Indeed, dust covered everything; it seemed to me the persistent

haze of nostalgia that protects all relics of childhood.

In the background, an assortment of pack furniture, trees, and shrubbery.

The sun moved lower in the sky, the shadows lengthened and darkened.

The more dust I removed, the more these shadows grew.

Summer arrived. The children

leaned over the rose border, their shadows

merging with the shadows of the roses. (1. 1-14)

5 At first sight, the old picture seems to be both a point of stasis and a starting point from which the poem unfolds. Yet it is also a moving image, as well as a double reflecting surface. Firstly, it reflects a time that is necessarily "calm and unmoving as in all photographs," (1.5) which is one characteristic of the "motionless" photograph as described by French semiologist Roland Barthes in Camera Lucida: "When we define the photograph as a motionless image, this does not mean only that the figures it represents do not move; it means that they do not emerge, do not leave: they are anesthetized and fastened down, like butterflies" (Barthes 1981: 57). Secondly, the 
photograph in Glück's poem, "A Summer Garden," is a reflecting surface through the consideration of something that is not caught in its frame. One specificity of this photograph is its non self-referentiality: the picture already designates what comes beyond, something that is out there and which the poem paradoxically tries to conceal in the very gesture of exposure. The frame of Glück's photograph does not contain what Barthes called punctum:

this element which rises from the scene, shoots out of it like an arrow, and pierces me. A Latin word exists to designate this wound, this prick, this mark made by a pointed instrument: the word suits me all the better in that it also refers to the notion of punctuation, and because the photographs I am speaking of are in effect punctuated, sometimes even speckled with these sensitive points; precisely, these marks, these wounds are so many points. (Barthes 1980: 26)

6 Consequently, in "A Summer Garden," the Spectator ${ }^{3}$ is not gripped by the emotion of a punctum. The photograph does not seem to hold the crucial detail endowed with a sharp poignancy. The surface of the image is smooth, the gesture of the hand stroking it and dusting it off calls attention to its surface rather than to its depth, suggesting a certain emotional restraint on the part of the lyrical instance: the first-person delays the origin of the pain until the fourth part of the poem (after sixty-four lines): "mother died last night, / Mother who never dies" (11. 64-5). The iterative present tense (used in the second line quoted above) tersely marks the irreversibility and the ineffability of the mourning process. Glück's poetics thus turns the experience of discovering a photograph "buried" (1.38) in the pages of an "ancient paperback" (1.24) into a scene where the dead "returns," in accordance with the law which Barthes discusses in Camera Lucida (1981: 9).

7 The whole poem is caught in the pulsation of time, oscillating between a static and impossible present tense and a phantasmatic ${ }^{4}$ past tense: "How quiet the garden is; / no breeze ruffles the Cornelian cherry" (1l. 43-4); "Winter was in the air, many months away" (1l. 66-7); "we could hear / Maria singing songs from Czechoslovakia-" (11. 72-3). "A Summer Garden" stages a vibrant and vibrating tableau vivant that is paradoxically and simultaneously held in the stasis of a staged moment ("how hushed it is, the stage / as well as the audience", 11.57-8). It is also caught in the inherent mutability and transformative process of time: "it was the tenth of May. / Hyacinth and apple blossom / bloomed in the back garden" (1l. 69-71). In "A Summer Garden," the form feeds and deforms the writing process by erasing the story the persona is trying to tell, as suggested by the following lines:

A word came into my head, referring

to this shifting and changing, these erasures

that were now obvious- (ll. 15-7)

\section{A displaced and translated punctum}

The dash at the end of line 17 marks the erasure on the page: the sign paradoxically shows what it means to conceal in black ink: oblivion, or, as the persona further explains, the magic word "referring / to these shiftings and changing [...] appeared, and as quickly vanished" (1l. 15-8). The dash, as a sign of an aposiopesis, gestures towards annihilation: the word will never be uttered or written and the voice is left groping in the dark: "was it blindness or darkness, peril, confusion?" (1. 19) 
The punctuation sign typographically figures what is left out of the picture, its blind spot-the punctum. The absence of the latter in the photograph is made visible: the moving point is erased even as the words are being written on the page: "The more dust I removed, the more these shadows grew." (1.12) On the contrary, the wiping gesture that was supposed to reveal details in the photograph acts as a darkening agent, contributing to the erasure and disappearance of the photograph as it is being placed again in the pages of the book:

2

When I had recovered somewhat from these events,

I replaced the photograph as I had found it

between the pages of an ancient paperback,

many parts of which had been

annotated in the margins, sometimes in words but more often

in spirited questions and exclamations

meaning "I agree" or "I'm unsure, puzzled" - [...]

Thus the little photograph

was buried again, as the past is buried in the future. (11. 22-38)

As the picture is being concealed, "buried again," before eventually being forgotten, the written text seems to take over, as shown by the polysemic verb "replace" (1. 23). Not only is the picture "placed again" in its former place, but the book comes as a substitute for the photograph: the clause "I replaced the photograph" is followed by the "spirited questions and exclamations / meaning 'I agree' or 'I'm unsure, puzzled'-" (1l. 27-8). But, as the persona indicates, these are not exactly "words" but "spirited questions and exclamations." The quotation marks do not indicate direct speech. The present participle "meaning" creates a breach between the "spirited questions and exclamations" written in the margins of the text and the statements "I agree" or "I'm unsure, puzzled." The double inverted commas, simple typographical signs, undermine the relation between voice and lyrical instance. The assertions in quotation marks are not direct quotes, their status is that of mere interpretations of the thoughts of another unknown and anonymous reader who owned an "ancient paperback" of Death in Venice - "ancient" conveys a remoteness that only strengthens the indirect relationship between the voice of the poem and the marginal comments. As the persona indicates, the book happens to be a translation:

I held the book awhile.

It was Death in Venice (in translation);

I had noted the page in case, as Freud believed,

nothing is an accident. (11. 33-6)

11 In focusing on the translated nature of the text, ${ }^{5}$ the poem tries to show and to conceal the irretrievable point of origin, the absent mother, the mother tongue, the original language that is always already lost between the pages and between the lines. ${ }^{6}$ These sections of the poem demonstrate the difficulty there is to see and read, the impossibility to write something new. The poem is already a repetition of countless past writings and the photograph a mere re-presentation, and the text a translation. Both photograph and novel beg to be interpreted and re-created by the reader. However, they are already texts produced mimetically or ekphrastically. Their textures both interweave the already written or seen, which is why they need to be overcome for the voice of the poem to be able to create something new.

Roland Barthes found the very essence of what his mother was to him, and the subtle nuances of her humanity, in a picture he called "the Winter Garden photograph" (1982: 
67). Here, in Louise Glück's summer garden, time has metamorphosed the image of the persona's mother "sitting in the sun, her face flushed as with achievement or triumph" (1. 2), turning her into a reified and sacred image, her face still glowing through time as a "relic" basking in "a haze of nostalgia" (1. 8).

Safeguarded by the "persistent / haze of nostalgia that protects all relics of childhood" (1l. 7-8) the sanctified character of the picture prevents all punctum from appearing to the Spectator. Nothing can protrude out of the surface of the photograph. The poignant detail is already being projected and displaced into the margins of the book (1l. 33-4). Moreover, in part two of the poem, the words are written in faded ink in the margins of Thomas Mann's novella:

The ink was faded. Here and there I couldn't tell

what thoughts occurred to the reader

but through the blotches I could sense

urgency, as though tears had fallen. (1l. 29-32)

What was an inability to see in the first part of the poem becomes an inability to read in the second part, as the first line of the second stanza indicates: "the ink was faded. Here and there I couldn't tell" (1.29). In cutting the verb "tell" from its object ("what thoughts occurred to the reader", 1.30) the enjambment creates a chiasmus between reading and "telling," as well as an interlacing between reader and lyrical instance: the reader/Spectator becomes the voice of the poem we are now reading. As the persona oscillates between the inability and the impossibility to see, Glück's poem points to the ineffectiveness of language: the interrogative form, the list of nouns-mere approximates-and the conjunction "or" underline not only the inability of the subject to see, but also the impossibility for language to communicate an intimate experience.

The penultimate stanza of the first section of the poem presents a wavering between "blindness or darkness, peril, confusion" (1.19) and the impossibility to read that is made blatant by the words written in faded ink, the contradictory signs of some "urgency" (1. 32). Through the enjambment in these two lines, "I could sense / urgency, as though tears had fallen" (1l. 31-32), the feeling of urgency is unhinged from the verb that produced it and is thus deferred with regards to the present of enunciation of the poem. Only traces of such urgency remain: "words in faded ink (1.29), blotches of tears" (1.31) and "two words, / linked by an arrow: 'sterility' and, at the bottom of the page, 'oblivion'-" (1l. 39-40). The graphic sign of the arrow comes at the end of a chain of deictics pointing outward, here, towards the bottom of the page and to the word "oblivion," which precedes a dash that itself gestures out of the stanza, out of the margin, out of the page -indeed, out of the book.

The "urgency" which the persona can read "through the blotches" can be read between the lines by the reader of the poem: once placed again in the book, "between the pages" of the novella, the photograph acts as a double deictic. Firstly, the picture naturally designates its referent (the mother in the summer garden); secondly, the photograph points to the "here and there" (1.29) of the reading process. Both of these referents seem to be worn out, at a remove from the present tense of the persona: the face of the mother covered in dust ("I wiped the dust from my mother's face", 1.6) and the "faded" words barely made decipherable "through the blotches" of tears (1.31). These erasures of time "that were now obvious" (1.17) conjure up the magic and the paradoxically unutterable word: "a word came into my head, referring / to this shifting and 
changing, these erasures / that were now obvious-" (1l. 15-17). The word will never be uttered, endlessly being erased in the writing process.

The photograph becomes a multiple translating agent: translating from one language to another, from the pictorial to the textual, it also transports the persona from a spectatorial to a readerly and, eventually, to a writerly -and even a lyrical- position:

In the margin there were two words,

linked by an arrow: "sterility" and, down the page, "oblivion"-

"And it seemed to him the pale and lovely

Summoner out there smiled at him and beckoned..." (11. 39-42)

The final couplet is a quotation from the last page of Death in Venice, when the protagonist and writer Aschenbach gazes at young Tadzio far away on the shore, as he is collapsing in his chair. Presented as the "Summoner," messenger of the gods, the boy announces the writer's death in the novella. The suspension dots at the end of the quote in the poem elliptically prolong the messenger's gesture, as the novella goes on: "as though with the hand he lifted from his hip, he pointed outward as he hovered on before into an immensity of richest expectation" (Mann 73). Left unsaid in the poem, this sentence remains concealed in the ink of the suspension dots. Like the Hermes figure in the novella, Glück's poem carefully stages a web of deictical agents pointing "outward": the punctum, the poignant detail, needs to be found outside the photograph. The text is a translation and, consequently, its own original vanishing point happens to be decentered. In the same way, at the end of section 4 of the poem, the body of the mother is presented with "her arms outstretched," (1.91) lengthening the Summoner's beckoning, pointing outward as well-outside the page, beyond life. Glück's writing pays close attention to typographical details, words written in the margins of the text. When the hypotext is quoted, the latter happens to point outward, towards somewhere out of reach, commanding us readers to turn the page and read on. The text also commands the persona of the poem to move on by letting go of emotions as towards death: "When I had recovered somewhat from these events, / I replaced the photograph as I had found it" (11. 22-3).

Moreover, in the last stanza of the penultimate section, the detail of the mother's head "balanced between [her arms]" constitutes the punctum missing from the summer garden photograph, its essential, moving point:

Mother slept in her bed,

her arms outstretched, her head

balanced between them. (11. 90-2)

The mundanity of the punctum makes it almost invisible, but the poem makes sure it is heard through its prosody. In the last stanza, the reader notices a swaying rhythm and alliteration in /b/ and in /d/: "mother slept in her bed, / her arms outstretched, her head / balanced between them," even in similar plosives, notably / $t /$ : slept, outstretched, between. This alliteration is underlined by epanalepsis in /ð/: mother / them, as well as the assonance in /e/ (or / $\varepsilon /$ : slept, bed, outstretched, head) which contribute to the rocking rhythm of the poem. The punctum happens to be doubly moving: not only does it move the reader, but it has also been displaced, translated towards the margins of the poem, near the end. Consequently, the whole poem has been turned into what Roland Barthes calls a "blind field," that is, into an invisible area outside the picture frame to which the punctum in the photograph points. It is not the flushed face of the mother in the summer garden that irradiates across the whole collection of Faithful and Virtuous Night. Through the multiple displacements caused by 
webs of deictics, the semantical, graphemical and typographical signs pointing outward, the wound has been decentered, the expression of grief has been deferred-all the more so since this section (part 4) was not included in the poem's first publication (issue of Poetry, January 2012), but appeared in the 2014 collection entitled Faithful and Virtuous Night. The punctum has exceeded the bounds of the poem, it is not in the photograph, and it has even been deferred in the history of the poem's publication: it is only in this penultimate section that the mother's death is made explicit ("mother died last night, / mother who never dies", 1l. 64-5).

\section{A stammering poetics}

Summoned by the Summoner-whose spelling only adds the syllable "on" to "summer,"- the reader of "A Summer Garden," moves on, so to speak, albeit through a time that seems to be stuttering. The voice of the poem summons a stammering summer, as it were, which seemingly cannot go past the same image of "the children / lean[ing] over the rose border," caught in a speech that annihilates the word as soon as it is uttered:

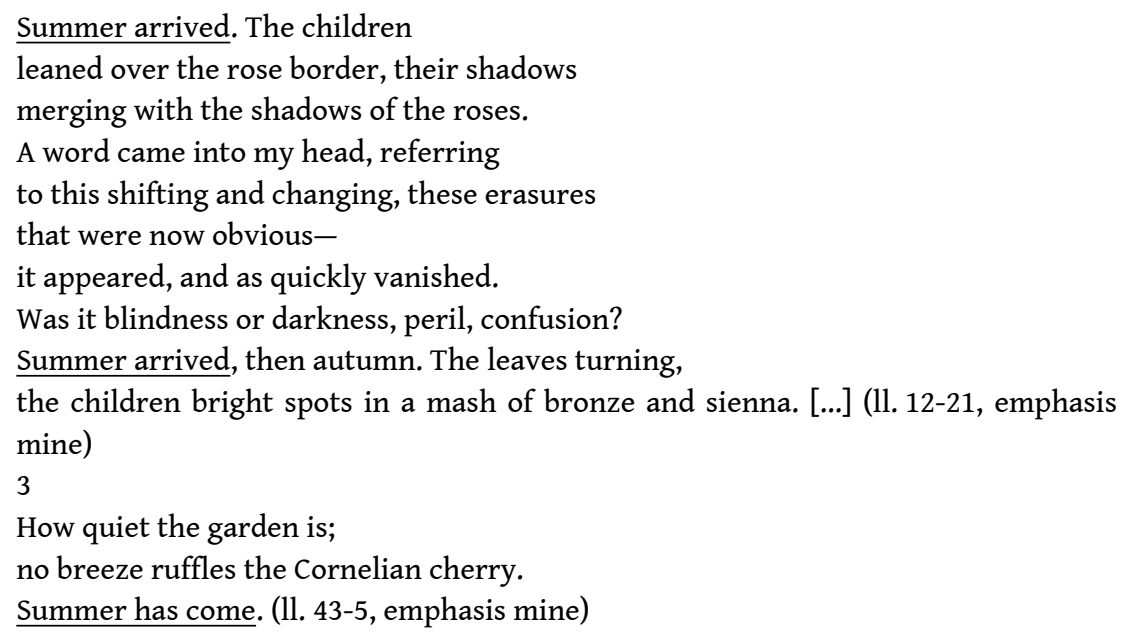

22 Time seems to be moving on the unstable grounds of a poetics which summons the coming of the season as if in a stutter. Indeed, summer is graphemically included in both verbs: it is the conflation of summ[on] and [stutt]er. The anaphoric repetition of the clause "summer arrived" (ll. 12, 20) in the preterit (rather than in the -ing form) makes it an impossible iteration -summer cannot "arrive" twice. Caught in the pulse of speech and time, the stammering enunciation also partakes of the metamorphosis of individuals. From this stammering time, there results a sense of urgency, which finds itself instilled in the words "peril, confusion" (1.19). These two words are proleptic, they anticipate and denounce an acceleration of time in the next stanza: they question the prolonged mental process of oblivion ("was it [...]?" 1.19), they make visible the corrosive process of time and the fading away of existence:

Summer arrived, then autumn. The leaves turning,

the children bright spots in a mash of bronze and sienna. (11. 20-1)

Before the enjambment, the intransitive verb "turning" twists the syntax and the image through the curve which the comma imprints at the end of the line. The absence of a verb on line 21 makes the metamorphosis evident, as if the intransitive "turning" had itself been turned into a transitive verb, thus turning the children into "a mash of 
bronze and sienna." Erasure is the main transforming force of the poem, where time acts as an expunging process: the figure of the children melts in the background ("a mash of bronze and sienna," "their shadows/merging with the shadows of the roses" 11. 13-4). However the erasure is presented as being already done, completed, as the absence of verb makes clear. Along with the twisted syntax and the ellipsis, the enjambment enhances the effect of erosion and erasure. Like the unreadable "blotches" of the faded ink in the margins of the translation, the ellipsis makes the children unrecognizable. This partakes in the "haze of nostalgia," which blurs memories whilst making them all the more vivid and poignant.

In the third section of the poem, the same paradox appears in a different form: as the second section concludes with the Summoner's beckoning-and with the writer's death -the third section opens with the arrival of summer in the present tense and the triumph of life in a morbid and sullen stillness:

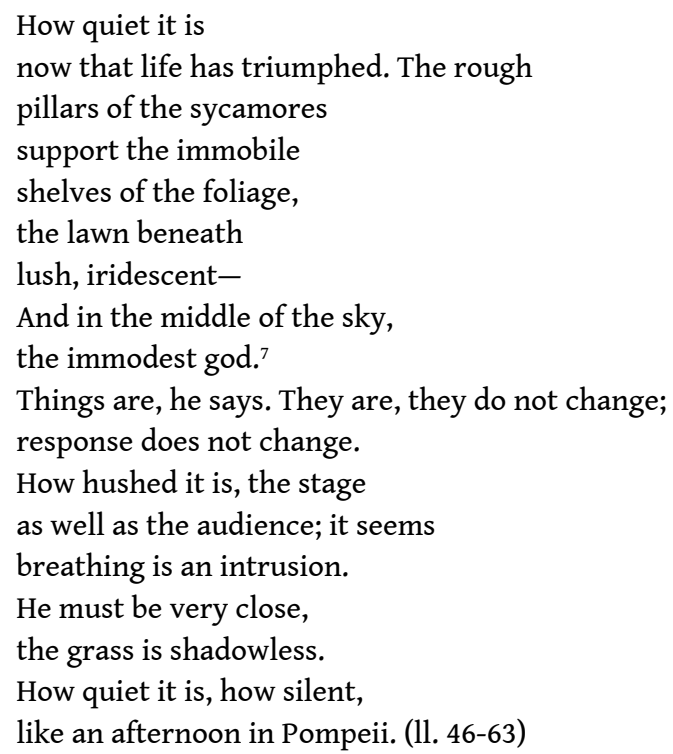

The morbid immobility of the scene exposes the artificiality of a silence that is displaced from the summer garden to a stage in a theater. Silence is here made oppressive but it is also filled with expectation: ${ }^{8}$ it is as if a personified Helios in papier mâché had come onto the stage and declared solemnly: "Things are, he says. They are, they do not change; / response does not change" (ll.55-6). However, across the enjambment the tone seems to have altered (in "response does not change"). There may be something in the poem's spelling this out, which gives the reader the feeling that the persona's subjectivity permeates the line, as in prosopopeia.

Response to death does not change throughout the poem. Besides, it can be pointed out that Glück's persona responds to death with double irony. Lines 46-7 ("how quiet it is / now that life has triumphed") sound all the more ironical that, in the novella, they come after the equally ironical scene of Aschenbach's death. The first stanza of section 3 presents the calm before the storm:

3

How quiet the garden is;

no breeze ruffles the Cornelian cherry

Summer has come

How quiet it is

now that life has triumphed. The rough 
pillars of the sycamores

support the immobile

shelves of the foliage,

the lawn beneath

lush, iridescent- (ll. 43-52)

The comparison with the destruction of Pompeii in the eruption of Mount Vesuvius ("how quiet it is, how silent. Like an afternoon in Pompeii", 11.62-3) reinforces this impression. As the sun reaches its zenith, "the grass is shadowless." Glück's writing turns into silence and the blinding light into deadly symptoms, the anticipatory signs of an imminent catastrophe: the phrase "these events" (in the allusive line "when I had recovered somewhat from these events", 1.22) is finally made explicit at the outset of section 4: "Mother died last night. / Mother who never dies" (1l. 64-5)-a section which was added a posteriori.

The repetition of absolute negation in the present tense strengthens the absurdity of the death of the mother, an irretrievability one finds in Barthes's note in his Mourning Diary: "In the sentence 'She's no longer suffering,' to what, to whom does 'she' refer? What does that present tense mean?" (Barthes 2012: 15). One may also wonder what this present tense means in "mother who never dies," (1.65) or, rather, with which value this iterative present is endowed. The negative sentence sounds wrong, or at least odd, since as surely as one lives only once, one dies only once. The unimaginable thing has happened: the persona's mother who could never die has just died. The simplicity of the sentence contradicts the complexity of the mourning process: how can one express one's loss without alienating it from one's intimacy, without "hystericiz[ing]" it, to use Barthes' term in his Mourning Diary.

The answer is embodied by the poem itself, with its form and wavering poetics. After a stifling summer, the voice seems to be already turning its attention towards winter. And yet, the chronology is upset once again, as if the landscape was seen through a trembling camera lens:

4

Mother died last night

Mother who never dies.

Winter was in the air,

many months away

but in the air nevertheless.

It was the tenth of May.

Hyacinth and apple blossom

bloomed in the back garden. (ll. 64-71)

The past tense surges back into the poem and tries to locate the moment of pain on a linear narrative: "winter was in the air," "it was the tenth of May." Here the past tense has the same function as in a novel, as Barthes explains in Writing Degree Zero, "it is a lie made manifest, it delineates an area of plausibility which reveals the possible in the very act of unmasking it as false" (Barthes 1968: 32). This function of the past tense may explain the introduction of the present tense in the contradiction mentioned earlier: "mother who never dies" turns the poem into what Roland Barthes referred to as "the receptacle of existence in all its density and no longer of its meaning alone" (Barthes 1968: 32). 


\section{A lyric, not a narrative} expressing vivid urgency in lyric form, it is an effort to articulate the unspeakable, to imprint the mutable and the unstable on the apparent linearity of poetic structure. The musicality of the prosody, which suddenly surges in the third stanza, helps overcome and disturb the causal chain and circumstantiality of the narrative. The single rhyme between "many months away" and "It was the tenth of May" (1l. 67, 69), for instance, contributes to the production of a mirror effect between these lines (the latter being a perfect iambic trimeter and the former an irregular trochaic trimeter). Moreover, the line: "but in the air nevertheless", further intensified by the stanza break, carves out an even deeper the rift between the two temporalities:

many months away

but in the air nevertheless

It was the tenth of May. (11. 67-9)

Not unlike the geological process of plate tectonics, Glück's poetics makes chronological time and subjective time slide towards and apart from one another. What may seem a simplistic poetic trope reconciles both temporalities, while affirming its utter impossibility-making "many months away" rhyme with "It was the tenth of May". This is also what the line break in the first stanza of the same section suggests:

Mother died last night

Mother who never dies.

The masculine rhyme ("away" / "May") and the line break in the couplet both mark the irremediable distance as well as the unbearable feeling of closeness to the mother's death. The musicality of language is introduced in the form of free verse, which a babbling of the tongue translates through the alliteration in plosives $/ \mathrm{d} /, / \mathrm{b} /, / \mathrm{p} /$ and /1/ in "Hyacinth and apple blossom/bloomed in the back garden" (1l. 70-1). The elegiac song is further detached from the flowing narrative and the roman typeface through the use of italics and a present tense in the passage that follows. The present tense grounds the voice of the poem in the lyrical urgency of an inevitable here and now, which the persona had so desperately tried to avoid from the beginning of the poem:

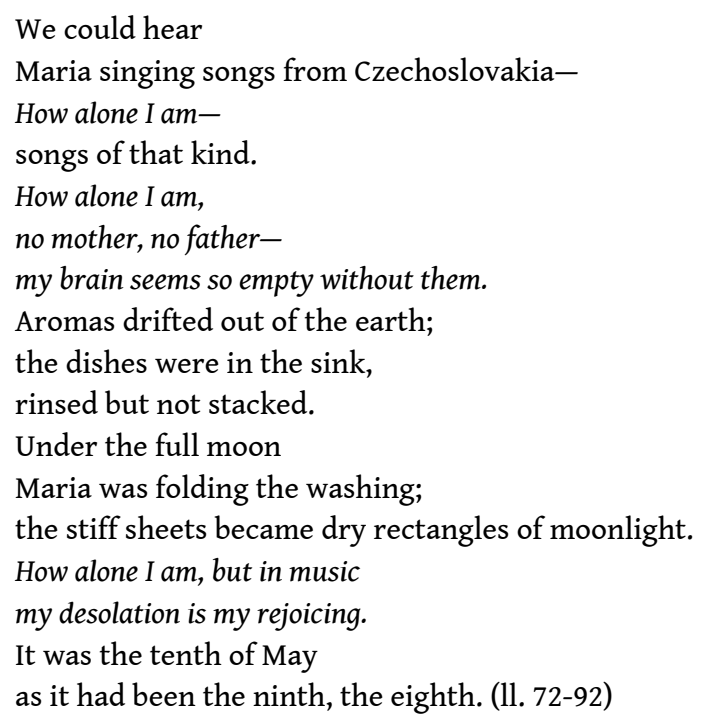

The songs are introduced through a narrative in the past tense, "we could hear / Maria singing songs from Czechoslovakia" (11. 72-3). It is not the first time the American poet 
has explicitly mentioned music from her Ashkenazi Jewish heritage, particularly klezmer music. ${ }^{9}$ Yet, in this instance, while reading the mournful lyrics in italics, the music coming to the reader's ears may call to mind Sidor Belarsky's Yiddish songs and lieder, the voice in the poem rather seems to echo that of soprano Maria Callas: "Maria singing songs from Czechoslovakia." ${ }^{10}$ The line interweaves varied references: classical operatic music and popular East European folk songs. The musical references are underscored by the assonances in $/ \mathrm{s} /, / \mathrm{z} /$ and $/ \delta /$ in "singing songs from Czechoslovakia"; "no mother, no father-/my brain seems so empty without them" (77-8), thus grounding them -along with the use of the italics- in the body of the text, of the singer, of the reader.

By staging this doleful song through direct speech and prosopopeia, the lyrical instance has led the reader to the apex of a lyrical expression that has tried to neutralize the writing and its own effects, flirting with the transitivity of writing and speaking. The voice of the poem is interrupted before the line break in section 2, for instance: "The ink was faded. Here and there I couldn't tell" (1. 29), while in the last lines of section 4, in the solitude of despair, the voice sings the loss of the beloved mother without giving in or giving up control over some devastating grief: "How alone I am, but in music / my desolation is my rejoicing" (11. 86-7).

To free oneself from constraint in such a controlled manner is an accomplishment echoed in the image of "the dishes [...] in the sink, / rinsed but not stacked" (1l. 80-1), hinting at incompleteness in a domestic order. Just as the song sounds out the words "my brain seems so empty without them," (1.78) the thoughts of a mind gone blank are projected on "stiff sheets [...] dry white rectangles of moonlight" (11. 84-5), similar to the musical scores belonging to a certain Maria. After the assonantal stanza that anchors the words in the body, the next stanza explores the music of speech and makes of the alliterations in /f/ and $/ \mathrm{S} /$ in "under the full moon / Maria was folding the washing; / the stiff sheets" (1l. 82-4) the physical extension of a reader's gestures. Indeed, the semantic, pictorial and phonematic characteristics of this line may be read and heard as the folding of the stiff sheets, but also as the smooth leafing through the pages of a book-of the "ancient paperback" of Death in Venice for instance.

\section{Terminus ad quem / a quo}

In a similar fashion, the enumeration of days in the penultimate stanza ("It was the tenth of May / as it had been the ninth, the eighth", 11. 88-9) can be read as a reverse countdown of days, but also as the numbering of pages, as the voice of the poem reminds us: "I had noted the page in case, as Freud believed, / nothing is an accident" (1l. 35-6). This counting down may also formulate the absurdity of life's approximation of the most traumatic event to the mundane, as if the triteness of death could be overcome through lyricism only. The poet needed both the operatic expressionism of Maria (Callas or not) and the desperate vitality ${ }^{11}$ of Eastern European music to make a decent "rejoicing of an unspeakable pain," in order to go beyond the relics of childhood and the sacred image exposed in the summer garden photograph. The image of the mother on her deathbed in the last stanza of section 4 happens to be more vivid, conveying more life than the one conjured in the photograph: 
Mother slept in her bed,

her arms outstretched, her head

balanced between them. (11. 90-2)

\section{Through the long poem "A Summer Garden," Glick's writing manages to turn the} ephemeral into something essential, as the double page of the collection stages itself in a multiple mise en abyme. The poem presents a structure of white rectangles fitting in one another: the "stiff sheets," the "dry rectangles of moonlight," (1l. 84-5) Maria's blank scores becoming the screens of a mind gone blank, an already forgotten photograph, "buried" (1.38) "between the pages of an ancient paperback" (1.24). All these are the prismatic projections of the mother's deathbed, the appearance of which is delayed almost until the end of the poem. "A Summer Garden" thus discusses, through its five sections, "something" that cannot be seen nor said, but that needs to be sung. More than a "blind field," there is also a blind spot which the persona of the poem cannot quite grasp, and which constitutes the decentered nadir of the poem, its displaced gravitational source. From the first-person, subjectivity shifts or drifts off to the third-person, by way of Beatrice:

5 Beatrice took the children to the park in Cedarhurst.

The sun was shining. Airplanes

passed back and forth overhead, peaceful because the war was over.

It was the world of her imagination:

true and false were of no importance. (1l. 93-7)

As a camera would zoom out, the image becomes more focused, as some geographical and temporal details are disclosed: the scene takes place in a park in Cedarhurst, a village in Nassau County, on the South shore of Long Island, New York, at the end of a war. The exact historical reference proves to be inconsequential, as is clearly asserted by the voice of the poem: "it was the world of her imagination: / true and false were of no importance" (1l. 96-7). After the preceding sections, which hovered in a rather abstract context, the historical and geographical references are abandoned as soon as they begin to be established.

41 The couplet "it was the world of her imagination / true and false were of no importance" brings the poem back to its very nature, to its intransitivity. In its countless efforts to name the small something, the "word [that] came into [her] head, referring / to this shifting and changing, these erasures / that were now obvious-" (ll. 15-7), the poem keeps translating the crucial word, the object of speech throughout its five sections. As the writing keeps blackening the page, Glück's poetics endlessly moves the crucial point, the punctum, the secret of the photograph outward, into the margins of the poem and even beyond. The poem traces a complex web of deictic signs which make "these shifting and changing, these erasures / [...] now obvious" (1l. 16-7), as in the final section:

The planes passed back and forth, bound

for Rome and Paris-you couldn't get there 
unless you flew over the park. Everything

must pass through, nothing can stop- [...] (1l. 101-4)

She sat on a bench, somewhat hidden by oak trees.

Far away, fear approached and departed;

from the train station came the sound it made. (1l. 110-2)

The endless coming and going of planes across the sky demonstrates the persistence of motion, of suspension, as "nothing can stop" (104). The back-and-forth motion of the planes figures the ebbing and flowing of the lines on the double page of the collection, ephemeral traces of words always already being erased in the writing process. Out of reach, "Rome and Paris" help stimulate a romantic imagination. They are dreamt cities, far away on the old Continent, while the park in Cedarhurst constitutes a grounded, anchored piece of land, as well as a necessary place of transition:

Beatrice took the children to the park in Cedarhurst

The sun was shining. Airplanes

passed back and forth overhead, peaceful because the war was over.

It was the world of her imagination:

true and false were of no importance.

Freshly polished and glittering-

that was the world. Dust

had not yet erupted on the surface of things.

[...]. Everything

must pass through, nothing can stop-

The children held hands, leaning

to smell the roses

They were five and seven. (1l. 93-100; 103-107)

The writing process presents mourning as a process of inevitable failure, constantly devouring itself and whose point of origin, whose traumatic point, is always already decentered, displaced, constantly deferred in the face of the infinity of time:

Infinite, infinite-that

was her perception of time. (11. 108-9)

In the face of the infinite, death is a question the last section of the poem does not pretend to answer, but which it merely tries to articulate. The last section presents what comes after the trauma, a Nachträglichkeit, a deferred action, "peaceful because the war was over" (1.95). The third stanza encapsulates the brilliance of a time caught in an après-coup, in a sparkling renaissance, but in the moment preceding oblivion:

Freshly polished and glittering-

that was the world. Dust

had not yet erupted on the surface of things. (1l. 98-100)

The imaginary tracing in the air, "where everything / must pass through, nothing can stop" (1l. 103-4), makes the portion of sky above the park in Cedarhurst "that piece of sky cut out by the soothsayer's staff." (Barthes 1994: 47) As Barthes had indeed noted, "the sky [is] the one thing that cannot be marked." It is written into the paradox of necessary transition, that "everything / must pass through," that the day should end, along with the poem:

The sky was pink and orange, older because the day was over.

There was no wind. The summer day

cast oak-shaped shadows on the green grass. (11. 113-5)

In contrast with the "mash of bronze and sienna" (1.21), the shadows of the children "merging with the shadows of the roses" (1.14) in the first section and the blazing light in section 3, where "the grass is shadowless" (1.61), the summer day finally casts "oak- 
shaped shadows on the green grass" in the last line of the poem, as if time had finally caught up with itself, as if the camera had finally found the right focus.

The poem traces the lines of what is literally a moving picture, taking in the erratic pain of a mourning subject in its striving to escape the infinity of time, while trying to overcome the absolute authority of death. Like the woeful songs coming from a distant -and now defunct-Czechoslovakia, the ephemeral traces of the planes across the sky above the park, the source of the coming and going sound of fear is syntactically offset by the hyperbaton "from the train station came the sound it made" (1.112). The tracing of the "oak-shaped shadows" could be equated with the attempts of any reader to decipher other people's handwritings and signs, their marginal words and phrases, like a soothsayer's staff trying to delimit the infinite. Glück's stammering-and yet expanding verse-demonstrates the futility of language and our helplessness in the face of death. Her poetics does not attempt to bridge the abyssal rift between language and life. Instead, through a work of constant deferral, through the intricate and interstitial hesitations imprinted on the texture of this long poem, the poet demonstrates that not only does each word matter, each word needs to be questioned. If Glück's lines have expanded, so have the webs of meanings wherein the unsaid develops in an even more intricate fashion. Through the experience of mourning, and through the study of a summer garden photograph, like Barthes's soothsayer's gesture, the poet shows how futile it is to want to "trace a limit of which immediately nothing is left, except for the intellectual remanence of a cutting out." (Barthes 1994: 47) The poetic persona discovers that it is vain to try to cut out rectangles of light, moments, fragments of life in order to reach for the irretrievable. In the face of an "infinite" (1. 108) time, "to devote oneself to the totally ritual and totally arbitrary preparation of a meaning" (Ibid.) is a mad gesture-and remains an absolute necessity.

\section{BIBLIOGRAPHY}

Barthes, Roland. Camera Lucida, Reflections on Photography [1980]. Trans. Richard Howard. New York: Hill and Wang, 1982.

Barthes, Roland. Mourning Diary [2009]. Trans. Richard Howard. New York: Hill and Wang, 2012.

Barthes, Roland. Roland Barthes by Roland Barthes [1975]. Trans. Richard Howard. Berkeley: U. of California P, 1994.

Barthes, Roland. The Neutral, Lecture Course at the Collège de France (1977-1978) [2002]. Trans.

Rosalind E. Krauss and Denis Hollier. New York: Columbia UP, 2005.

Barthes, Roland. Writing Degree Zero [1953]. Trans. Jonathan Cape. Boston: Beacon Press, 1970.

Glück, Louise. Averno. Manchester: Carcanet Press, 2006.

Glück, Louise. Faithful and Virtuous Night. Manchester: Carcanet Press, 2014.

Glück, Louise. Meadowlands. New York: HarperCollins, 1996. 
Glück, Louise. Proofs and Theories. Hopewell: Ecco Press, 1994.

Mann, Thomas. Death in Venice: A New Translation, Backgrounds and Contexts. Ed. Clayton Koelb. New York: W.W. Norton \& Company, 1994.

Vendler, Helen. The Ocean, The Bird, and the Scholar, Essays on Poets and Poetry. Cambridge: Harvard UP, 2015.

\section{NOTES}

1. The poem "A Summer Garden" was first published in Poetry (January 2012, available online: https://www.poetryfoundation.org/poetrymagazine/poems/detail/55237) and then, two years later, in 2014, in the collection Faithful and Virtuous Night. Interestingly enough, the first version of the poem is composed of four sections only, whereas the 2014 version unfolds across six pages and is composed of five parts, each one consisting of more than twenty lines.

2. "[W]hen poems are difficult, it is often because their silences are complicated, hard to follow. For me, the answer to such moments is not more language. What I am advocating is, of course, the opposite of Keats's dream of filling rifts with ore. The dream of abundance does not need another defense. The danger of that aesthetic is its tendency to produce, in lesser hands, work that is all detail and no shape" (Glück 1994: 82).

3. I am using the key notions of Spectator, Operator, Spectrum as Roland Barthes defines them in Camera Lucida: "The Operator is the Photographer. The Spectator is ourselves, all of us who glance through collections of photographs-in magazines and newspapers, in books, albums, archives... And the person or thing photographed is the target, the referent, a kind of little simulacrum, any eidolon emitted by the object, which I should like to call the Spectrum of the Photograph, because this word retains, through its root, a relation to 'spectacle' and adds to it that rather terrible thing which is there in every photograph: the return of the dead" (Barthes 1981: 9).

4. I am using "phantasmatic" in its sense of "relating to or of the nature of a phantasm; phantasmal, incorporeal, illusory" (OED).

5. The phrase "in translation" is indicated in parentheses, attention is drawn to the book as an artefact as the persona considers it for a while, "I held the book awhile" (1l. 33, 34).

6. The English translation of Thomas Mann's Der Tod in Venedig (1912) quoted by Glück is by Clayton Koelb (Mann 1994: 73).

7. The reference to "the immodest god" Helios "in the middle of the sky" recalls Mann's numerous mythological references in Death in Venice and, more particularly, the beginning of chapter IV, with the reference to Helios in his chariot of fire. Glück often makes mythological references, as in "A Myth of Innocence" in Averno, partly voicd by Persephone, aswhen she ibeing abducted by Hades: "The sun seems in the water, very close. / That's my uncle spying again, she thinks-" (Glück 2006: 50, 7-8).

8. The stage is also referred to in the first stanza of "Afterword," a poem from the same collection: "Reading what I have just written, I now believe / I stopped precipitously, so that my story seems to have been / slightly distorted, ending, as it did, not abruptly / but in a kind of artificial mist of the sort / sprayed onto stages to allow for difficult set changes" (Glück 2013: 30, 1-5).

9. In the poem "Moonless Night" published in the collection Meadowlands, , a small band called the Lights is "practising klezmer music" (Glück 1996: 9, 4).

10. It would not be the first time that the poet referred to Maria Callas: in the collection Meadowlands, the opening poem "Penelope's Song" refers to the voice of the opera singer: "call out to him over the open water, over the bright water / with your dark song, with your grasping, / unnatural song-passionate, / like Maria Callas" (Glück 1996: 3, 11-4). 
11. "Desperate vitality" is an expression Roland Barthes used in his Lecture Course on the Neutral in 1978 and which he took from Pasolini, as indicated in a note: “'Una disperata vitalità' is the title of one of the poems collected in Pier Paolo Pasolini's Poesia in forma di rosa. Barthes will read its last stanza twice during the course: the first time at the opening of the March 4 session and the second at the end of 'Images of the Neutral,' at the start of the March 18 session" (Barthes 2005: 216).

\section{ABSTRACTS}

The article proposes a reading of the poem "A Summer Garden" by contemporary American poet Louise Glück. The poem is from her recent collection, Faithful And Virtuous Night (2014), signalling a radical change of style for the author, with the shift to longer, seemingly more narrative, poems and to prose poems. Our intention here is to read "A Summer Garden", a poem of mourning, with the help of Roland Barthes, who discovered in "the Photograph of the Winter Garden" the truth about his mother, who had died three years before the publication of $L a$ Chambre claire in 1980. Louise Glück's “A Summer Garden" starts with the discovery of a photograph of the mother of the poem's persona. The mother is sitting in a summer garden where time seems to have stopped, to be caught in a temporal interstice and in the insistent repetition of a summer which never seems never to come. We shall examine how Glück's poetics decentres and defers the punctum of her summer garden photograph, by convening a constellation of deictics, of signs pointing outwards, to what is beyond the frame. While the pages turn black in Glück's writing, the multiple screens which the poem stages stay obstinately blank, as language remains powerless in the face of grief paradoxically rendered impossible through writing.

L'article propose une lecture du poème «A Summer Garden» de la poète américaine contemporaine Louise Glück. Il est tiré de son dernier recueil, Faithful And Virtuous Night (2014), qui confirme un changement de style radical dans le parcours de l'auteure, avec des poèmes plus longs, apparemment plus narratifs, et des poèmes en prose. Nous nous proposons de lire « $\mathrm{A}$ Summer Garden », poème de deuil, à travers le regard de Roland Barthes qui avait trouvé en « la Photo du Jardin d'Hiver " la vérité de sa mère, décédée trois ans avant que ne soit publié La Chambre claire en 1980. "A Summer Garden" de Louise Glück s'ouvre sur la découverte d'une photographie de la mère de la persona, assise dans un jardin d'été où le temps semble s'être arrêté, pris dans l'oscillation et la répétition insistante d'un été qui semble ne jamais advenir. Nous étudions comment la poétique de Glück décentre et diffère le punctum de sa photographie du jardin d'été au moyen d'une constellation de déictiques, de signes qui montrent le dehors, le hors-champ. Alors que les pages se noircissent chez Glück, les multiples écrans que le poème met en scène demeurent obstinément vierges, le langage impuissant face à un chagrin que l'écriture rend paradoxalement impossible. 
INDEX

Keywords: Glück Louise, mourning, photography, punctum, deferment, Barthes Roland, American poetry

Mots-clés: Glück Louise, deuil, photographie, punctum, diffèrement, Barthes Roland, poésie américaine

\section{AUTHOR}

MARIE OLIVIER

Marie Olivier is an associate professor in American literature at Université Paris Est Créteil Val de Marne. She is a member of the IMAGER EA 3958 research laboratory. Her research is focused on contemporary American poetry, literary theory, and on relations between music and literature. Contact: marie.olivier [at] u-pec.fr 